\title{
Empirical Analysis on China's International Competitiveness in Service Trade
}

\author{
Tian yuli \\ School of Economics and Management \\ Shandong Women's University \\ Jinan, China \\ e-mail: jadebeautiful@163.com
}

\begin{abstract}
China has become an important country of service trade in the world. This paper calculates and analyzes the competitiveness of service trade by using the proportion of trade in goods and trade in services, industry structure and regional sturcture of service trade. We can reach the conclusion that Chinese service trade is on a low level of overall development, and especially the structure is still in relatively backward. So the positive and effective development strategies and measures should be taken to deal with the problem which exist in Chinese service trade such as structure backwardness,weak international competitiveness and imbalance on import and export.
\end{abstract}

Keywords-competitive advantage; industry structure, regional concentration degree

\section{INTRODUCTION}

With the development of the international trade, services trade begin to play a more and more important role in one country's international competitiveness. In this paper, the structure and the international competitiveness of services trade is analyzed by using the the basic international trade therory, so we can find the problems which exist in the Chinese service trade and provide the theroy and empirical basis for further improving the level of the China services trade.

\section{The Current Situition of China SERVICE Trade}

\section{A. The Amount of Service Trade Analysis}

The amount of service trade can reflect the general development trend. From the figure1, we can find that Chinese service trade is graduately devloping from 2001, only in 2009, it was decreased because of the impaction of the worl financial crisis.

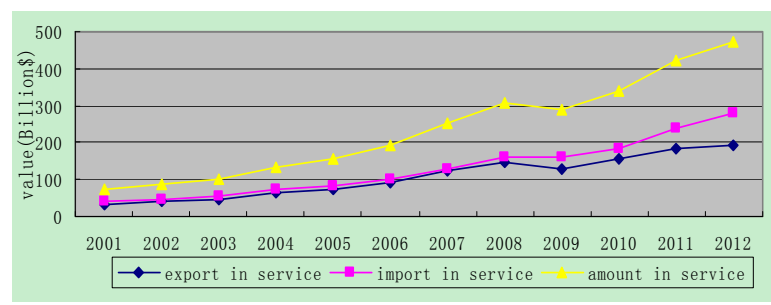

Figure 1. the amount of the service trade

Data Resource: statistical analysis according to the UNCTAD data

\section{B. The Balance of Service Trade Analysis}

The balance of services trade can reflect the export competitiveness of services trade. From table1, we can find that Chinese services trade has always been in a deficit state and the gap size increased year by year since 2006.

TABLE I. The Balance Of Service Trade

\begin{tabular}{|l|l|l|l|l|l|l|l|}
\hline Service & $\mathbf{2 0 0 6}$ & $\mathbf{2 0 0 7}$ & $\mathbf{2 0 0 8}$ & $\mathbf{2 0 0 9}$ & $\mathbf{2 0 1 0}$ & $\mathbf{2 0 1 1}$ & $\mathbf{2 0 1 2}$ \\
\hline export & 47 & 62 & 74 & 92 & 122 & 147 & 130 \\
\hline import & 55 & 72 & 84 & 101 & 130 & 159 & 159 \\
\hline balance & -9 & -10 & -9 & -9 & -8 & -12 & -29 \\
\hline
\end{tabular}

Data Resource: statistical analysis according to the UNCTAD data

III. The REVEALED COMPARATIVE AdVANTAGE AND COMPETITIVE AdVANTAGE ANALYSIS OF CHINA SERVICE TRADE

\section{A. The Competitive Advantage Analysis of China Service} Trade

We can use Trade Competitiveness Index to estimate the trade competitive advantage of one country's industry, and it can be indicated as follow equation:

$$
T C_{i k}=\frac{X_{i k}-M_{i k}}{X_{i k}+M_{i k}}
$$

In this equation, $\mathrm{TC}_{\mathrm{ik}}$ means the country $i$ Trade Competitive Advantage (TC) index of industry $k, \mathrm{X}_{\mathrm{ik}}$ means the country $i$ export volume of industry $k, \mathrm{M}_{\mathrm{ik}}$ means the country $i$ import volume of indusry $k$. If $\mathrm{TC}_{\mathrm{ik}}>0$, that means country $i$ has the trade competitive advantage of $k$ industry, and vice versa. In my paper, I use the United Nations service industry classification standard and the UNCTAD data to calculate the TC index of China's service trade from 2007 to 2011, and the calculation results are as table2:

TABLE II. THE TC INDEX Of SERVICE TRADE By INDUSTRY

\begin{tabular}{|l|l|l|l|l|l|}
\hline \multicolumn{1}{|c|}{ Industry } & $\mathbf{2 0 0 7}$ & $\mathbf{2 0 0 8}$ & $\mathbf{2 0 0 9}$ & $\mathbf{2 0 1 0}$ & $\mathbf{2 0 1 1}$ \\
\hline Total services & -0.03 & -0.04 & -0.10 & -0.06 & -0.13 \\
\hline Transport & -0.16 & -0.13 & -0.33 & -0.30 & -0.39 \\
\hline Travel & 0.11 & 0.06 & -0.05 & -0.09 & -0.20 \\
\hline Communications & 0.04 & 0.02 & 0.00 & 0.04 & 0.24 \\
\hline Construction & 0.30 & 0.41 & 0.23 & 0.48 & 0.60 \\
\hline Insurance & -0.84 & -0.80 & -0.75 & -0.80 & -0.71 \\
\hline Financial services & -0.41 & -0.28 & -0.25 & -0.02 & 0.07 \\
\hline Computer and information & 0.33 & 0.33 & 0.34 & 0.51 & 0.52 \\
\hline Royalties and licence fees & -0.92 & -0.90 & -0.93 & -0.88 & -0.89 \\
\hline
\end{tabular}




\begin{tabular}{|l|l|l|l|l|l|}
\hline Other business services & 0.14 & 0.09 & 0.14 & 0.28 & 0.24 \\
\hline Government services n.i.e. & -0.22 & -0.16 & 0.06 & -0.09 & -0.22 \\
\hline Commercial services & -0.03 & -0.04 & -0.10 & -0.06 & -0.13 \\
\hline Other commercial services & -0.03 & -0.03 & -0.02 & 0.10 & 0.08 \\
\hline
\end{tabular}

Data Resource: statistical analysis according to the UNCTAD data

\section{B. The Reveal Comparative Advantage Analysis of China Service Trade}

The most popular measurement index of comparative advantage is the Revealed Comparative Advantage (RCA), first developed by American economist Balassa in 1965, RCA index can be indicated as follow equation:

$$
R C A_{i k}=\frac{X_{i k} / X_{i}}{X_{w k} / X_{w}}
$$

In this function, $R C A_{i k}$ means the country $i$ Revealed Comparative Advantage (RCA) index of industry $k, X_{i k}$ means the country $i$ service trade export volume of industry $k, X_{i}$ means the whole service trade export volume of country $i, X_{w k}$ means the whole world service trade export volume of industry $k, X_{w}$ means the whole world service trade export volume. If $R C A_{i k}>1$, that means country $i$ has the comparative advantage of industry $k$, and vice versa. In this paper, we use the UNCTAD service industry classification standard and data to calculate the RCA index of China service trade in recent five years, the calculation results are as table3:

TABLE III. The RCA INDEX Of SERVICE TRADE By INDUSTRY

\begin{tabular}{|l|l|l|l|l|l|}
\hline \multicolumn{1}{|c|}{ Industry } & $\mathbf{2 0 0 7}$ & $\mathbf{2 0 0 8}$ & $\mathbf{2 0 0 9}$ & $\mathbf{2 0 1 0}$ & $\mathbf{2 0 1 1}$ \\
\hline Transport & 1.17 & 1.15 & 0.93 & 0.97 & 0.96 \\
\hline Travel & 1.22 & 1.13 & 1.22 & 1.08 & 1.05 \\
\hline Communications & 0.40 & 0.43 & 0.35 & 0.29 & 0.38 \\
\hline Construction & 1.80 & 2.52 & 2.59 & 3.44 & 3.37 \\
\hline Insurance & 0.34 & 0.44 & 0.54 & 0.48 & 0.90 \\
\hline Financial services & 0.02 & 0.03 & 0.05 & 0.11 & 0.06 \\
\hline Computer and information & 0.77 & 0.83 & 0.90 & 0.96 & 1.13 \\
\hline Royalties and licence fees & 0.05 & 0.07 & 0.05 & 0.08 & 0.07 \\
\hline Other business services & 1.36 & 1.30 & 1.39 & 1.40 & 1.40 \\
\hline $\begin{array}{l}\text { Personal, cultural and } \\
\text { recreational services }\end{array}$ & 0.22 & 0.27 & 0.06 & 0.06 & 0.07 \\
\hline Government services & 0.23 & 0.26 & 0.39 & 0.31 & 0.21 \\
\hline $\begin{array}{l}\text { Memo item: Commercial } \\
\text { services }\end{array}$ & 1.02 & 1.01 & 1.01 & 1.01 & 1.01 \\
\hline $\begin{array}{l}\text { Memo item: Other } \\
\text { commercial services }\end{array}$ & 0.85 & 0.90 & 0.94 & 1.00 & 1.02 \\
\hline
\end{tabular}

Data Resource: statistical analysis according to the UNCTAD data

\section{The Structure Of Services Trade}

\section{A. the Proportion Between the Trade in Services and the Trade in Goods Relationship Analysis}

The proportion of service trade and goods trade is one of the important index which can reflect the service trade optimization extent. In order to find the real relationship between the service trade and the goods trade, we run a regression analysis between the ratio of the goods trade $\left(\mathrm{T}_{\mathrm{g}}\right)$ and the service trade $\left(T_{s}\right)$ that is $\left(T_{g}\right) /\left(T_{s}\right)$ and the logarithm of GDP per capita by using the recent 30 years data of America and get the figure2, and we can get the conclusion that the ratio of trade in goods and services trade $\left(\left(\mathrm{T}_{\mathrm{g}}\right) /\left(\mathrm{T}_{\mathrm{s}}\right)\right)$ and the logarithm GDP per capita conform to the simple linear regression.

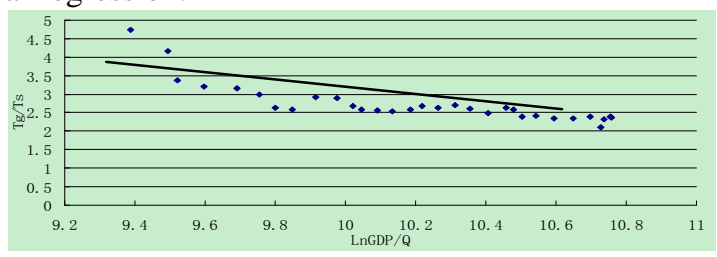

Figure 2. A scatter diagram between $\mathrm{T}_{\mathrm{g}} / \mathrm{T}_{\mathrm{s}}$ and LnGDP/Q Data Resource: statistical analysis according to the UNCTAD data

According to almost 30 years of data of the United States and using OLS to estimate, we can get the fitted equation (2):

$$
\frac{\left(T_{g}\right)}{\left(T_{s}\right)}=13.51-1.05 \ln \frac{G D P}{Q}(2)
$$

The data in braketsis t value, **means it is significant at the $99 \%$ level. By using the test result, we can get the conclusion that the United States trade data has the remarkable representative, so we can use equation (1) as a measure whether the trade in service structure is optimized. According to the equation (1), it means that GDP per capita of value increased by $1 \%$, the proportion of trade in goods and trade in services should be decreased 1.05 units. So we can contrast the real value and the fitted value of $\left(T_{g}\right) /\left(T_{s}\right)$ by using the equation (1) and get the table3:

TABLE IV. The Balance Of Service Trade

\begin{tabular}{|l|c|c|c|c|c|}
\hline Year & $\mathbf{2 0 0 1}$ & $\mathbf{2 0 0 2}$ & $\mathbf{2 0 0 3}$ & $\mathbf{2 0 0 4}$ & $\mathbf{2 0 0 5}$ \\
\hline Real Tg/Ts & 7.02 & 7.20 & 8.34 & 8.58 & 8.99 \\
\hline Fitted Tg/Ts & 6.02 & 5.94 & 5.85 & 5.75 & 5.64 \\
\hline Year & $\mathbf{2 0 0 6}$ & $\mathbf{2 0 0 7}$ & $\mathbf{2 0 0 8}$ & $\mathbf{2 0 0 9}$ & $\mathbf{2 0 1 0}$ \\
\hline Real Tg/Ts & 9.13 & 8.62 & 8.37 & 7.65 & 8.72 \\
\hline Fitted Tg/Ts & 5.52 & 5.39 & 5.30 & 5.21 & 5.12 \\
\hline
\end{tabular}

Data Resource: statistical analysis according to the UNCTAD data

According to the real value and the fitted value of the $\left(T_{g}\right) /\left(T_{s}\right)$, we can reach the conclusion that the real value of the $\left(T_{g}\right) /\left(T_{s}\right)$ is far exceed the fitted value, and that means the development level of China's service trade is low. Howervr, it appears the optimized trend.

\section{B. Industry Stucture Analysis of Trade in Services}

1) Industry stucture analysis of export trade in services: By analyzing the industries' export amount and the devlopment trend of China's export trade in service from 2001 to 2012, we can obtain the information that the export of trade in service is concentrated in the travle, transport and commerce business industries, the consultation industry is the fastest development industry in the export trade in service, and other industries' development speed is slow. We can find the development trend of export trade in service in figure3. 


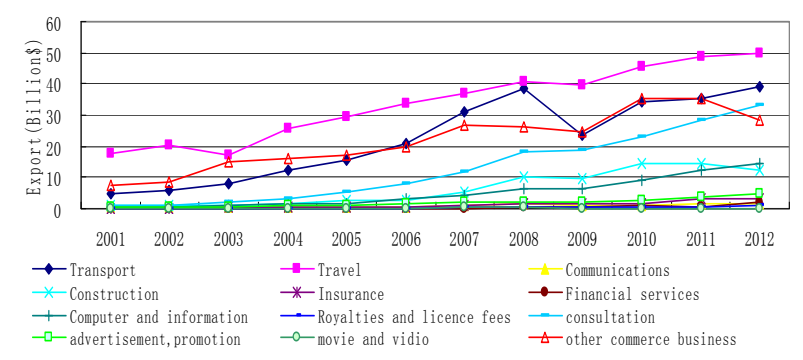

Figure 3. Industry structure of export trade in service Data Resource: statistical analysis according to the UNCTAD data

2) Industry stucture analysis of import trade in services: By analyzing the industries' import amount and the devlopment trend of China's import trade in service from 2001 to 2012, we can obtain the information that the import of trade in service is concentrated in the travle and transport industries, all of other industries' development speed is slow. We can find the development trend of export trade in service in figure4.

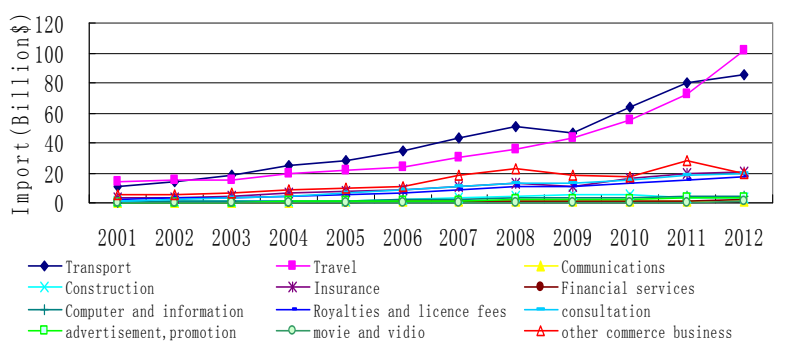

Figure 4. Industry structure of import trade in service Data Resource: statistical analysis according to the UNCTAD data

3) Industry stucture analysis of balance trade in services: By analyzing the devlopment trend of the balance trade in service situation from 2001 to 2012, we can find that the industries which are in the favorable balance of trade include construction, consultation, computer and information and commerce business, however, transport, travel, insurance and royalties and license fees industries are all in the infavorable balance of trade. From figure5, particularly noteworthy is that the tourism industry changed quickly from surplus to deficit since 2008, and it becomes the largest trade deficit industry now. Another notable industry is the transport industry - its trade deficit have expanded rapidly in recent years.

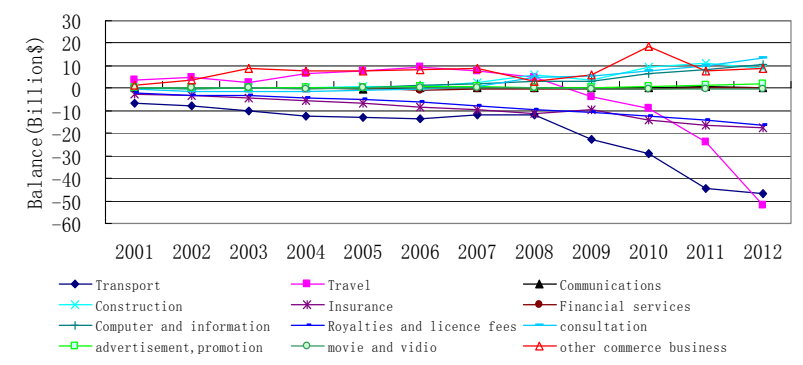

Figure 5. Industry structure of balance trade in service Data Resource: statistical analysis according to the UNCTAD data

\section{Regional Structure Analysis of Trade in Services}

In my paper, I use the time series analysis method and regional concentration degree to analyze the regional structure of the trade in services. By using the proportion of the different area import or export amount in different industries, we can acknowledge the current regional structure situation of the trade in services. Considering the availability of data and service trade industry situation in China, this paper adopted the transport, tourism and commerce business industry data which is from the WTO official statistics.

1) Regional structure analysis of transportations trade: In my paper, I used six typical countries and regions (EU, USA, Hongkong, Japan, Korea, Singapore, other counties) data to ananlyze the regional structure devlopment trend from 2005 to 2010.

a) Regional structure analysis of export transportation trade: By analyzing the export regional structure development trend of China's services trade in transportation industry, we can find that most countries export proportion is in a stable state or in slow decline in scale except EU and other countries (in figure6). That means regional concentration degree of transportation export trade is reducing.

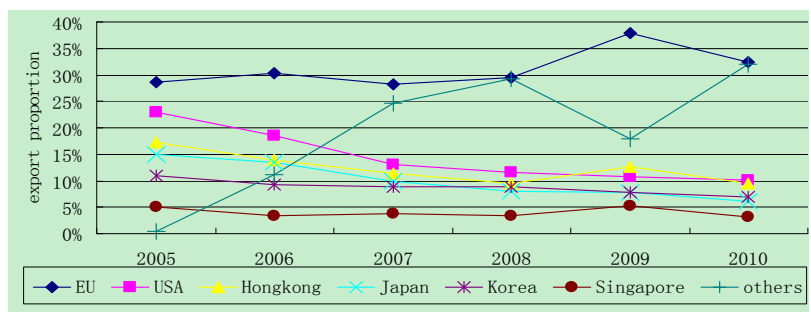

Figure 6. regional structure of transportation export trade Data Resource: statistical analysis according to the WTO data

b) Regional structure analysis of import transportation trade: By analyzing the import regional structure development trend of China's services trade in transportation industry(in figure7), we can find that regional concentration degree of transportation import trade is in a stable state..

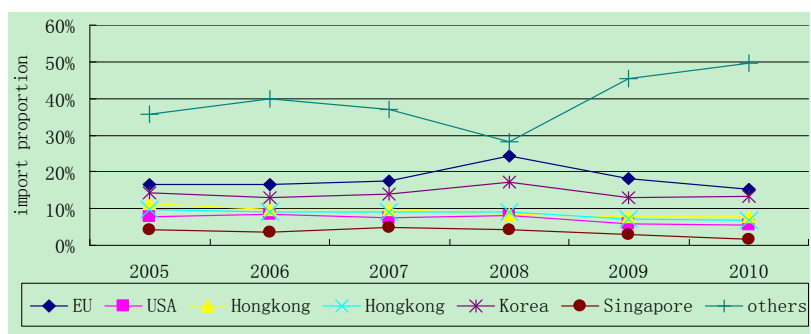

Figure 7. regional structure of transportation import trade Data Resource: statistical analysis according to the WTO data

c) Regional structure analysis of transportation trade balance: By analyzing the trade balance regional structure development trend of China's services trade in transportation industry(in figure8), we can find that China's 
transportation trade deficit comes mainly from South Korea and other countries. The main reason is China's trade deficit in goods mostly comes from these countries.

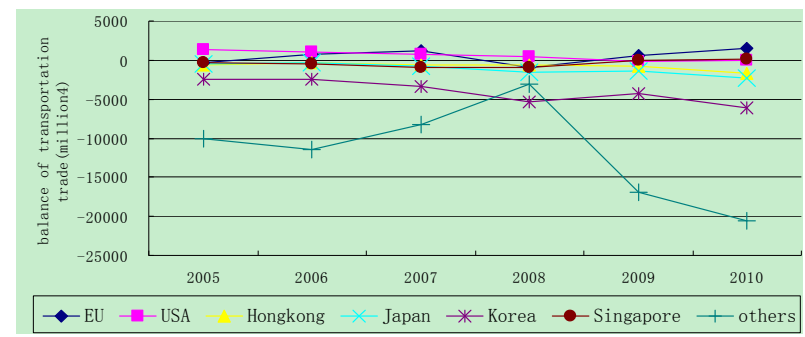

Figure 8. regional structure of transportation banlance trade Data Resource: statistical analysis according to the WTO data

2) Regional structure analysis of travel trade: In my paper, seven typical countries and regions (EU, USA, Hongkong, Austrilia, Russian, Japan, Korea,other countries) data is used to ananlyze the regional structure devlopment trend from 2005 to 2010.

a) Regional structure analysis of export travel trade: By analyzing the export regional structure development trend of China's services trade in travel industry(in figure9), we can find that most countries export proportion is in a stable state.

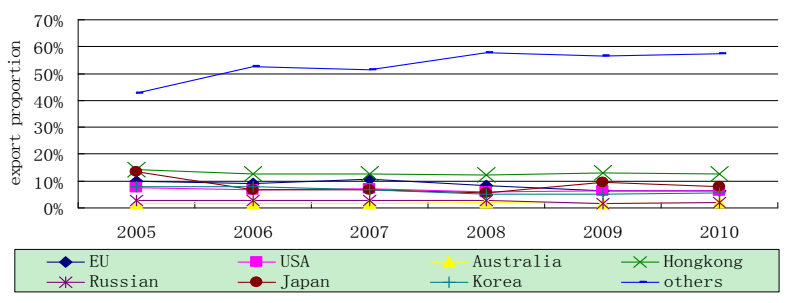

Figure 9. regional structure of travel export trade Data Resource: statistical analysis according to the WTO data

b) Regional structure analysis of import travel trade: By analyzing the import regional structure development trend of China's services trade in travel industry (in figure10), we can find that most countries import proportion is in a stable state except Hongkong and other countries.

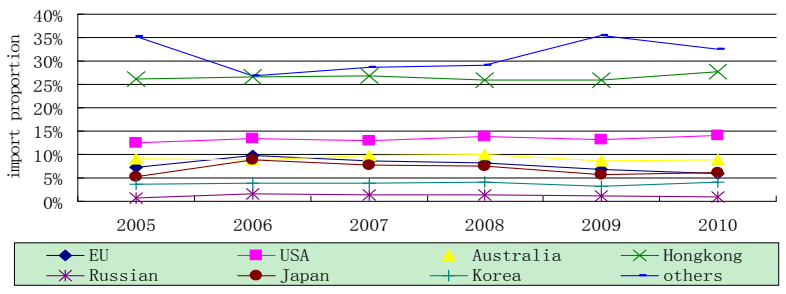

Figure 10. regional structure of import travel trade Data Resource: statistical analysis according to the WTO data

c) Regional structure analysis of travel trade balance: By analyzing the trade balance regional structure development trend of China's services trade in travel industry (in figure11), we can find that China's travel trade deficit comes mainly from United States, Austrilia and
Hongkong, and most countries are in trade balance except other countires.

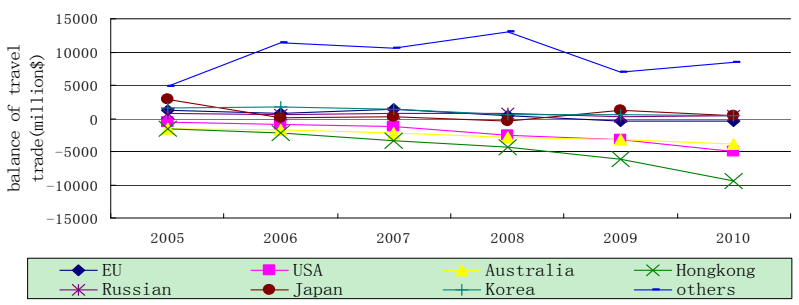

Figure 11. regional structure of travel trade banlance

Data Resource: statistical analysis according to the WTO data

3) Regional structure analysis of other commerce business: In my paper, I used seven typical countries and regions (EU, USA, Hongkong, Singapore, Russian, Japan, Korea and other countries) data to ananlyze the regional structure devlopment trend from 2005 to 2010.

a) Regional structure analysis of other commerce business export trade: By analyzing the export regional structure development trend of China's services trade in other commerce business(in figure12), we can find that most countries export proportion is in a stable state.

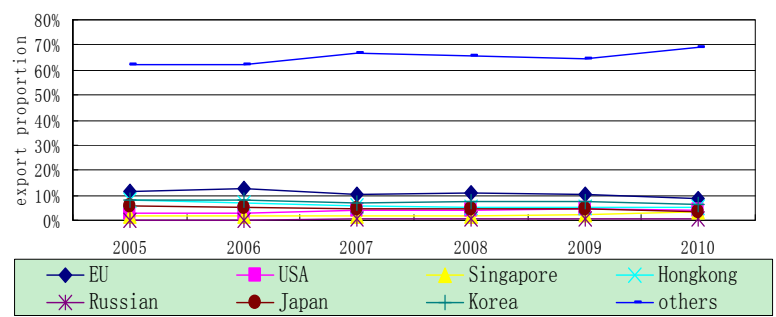

Figure 12. regional structure of other commerce business export trade Data Resource: statistical analysis according to the WTO data

b) Regional structure analysis of other commerce business import trade: By analyzing the import regional structure development trend of China's services trade in other commerce business (in figure13), we can find that most countries import proport is in a stable state except other countries.

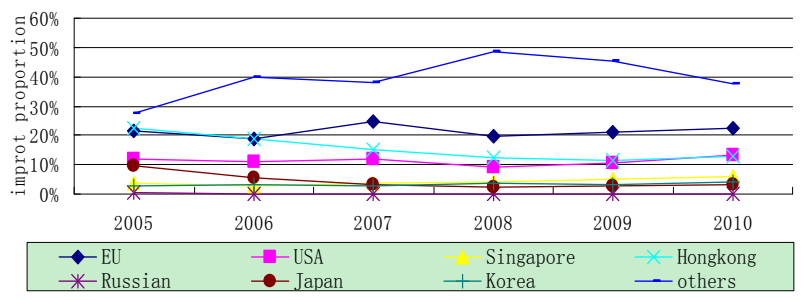

Figure 13. regional structure of import travel

Data Resource: statistical analysis according to the WTO data

c) Regional structure analysis of other commerce business trade balance: By analyzing the trade balance regional structure development trend of China's services trade in other commerce business(in figure14), we can find that China's other commerce business trade deficit comes 
mainly from United States, EU and Hongkong, and ohter countries are in trade surplus.

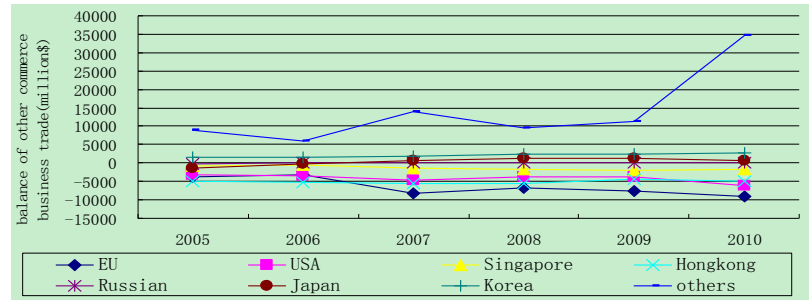

Figure 14. regional structure of other commerce business trade banlance Data Resource: statistical analysis according to the WTO data

\section{COnClusion And Suggestion}

\section{A. Conclusion of China Trade in Services}

1) The Current situation of China trade in services : From the analysis of current situation of China trade in service, we can reach the conclusion that the amount of the China trade in service is in a slow rising trend, however, the balance of the trade in service is in a deficit state and the deficit rate is increasing. All of this means that China trade in service is weak.

2) The comparative advantage and the competitive advantage of China trade in services: From the view of international competitiveness of China trade in service, we can conclude that the computer and information service industries have competitive advantage in the world, however, Royalties, licence and insurance services industries are in the competitive weakness state, and that means these industries development level is low. From the perspective of comparative advantage, we can find that construction and business service industries have strong comparative advantage, other industries are all in the comparative disadvantage state.

3) The industry structure of China trade in services : According the figure 3 , figure 4 and figure 5 , the industry structure of China trade in service has changed dramatically in recent years. Transport and travel services are two most obvious import and export amount increased industries, at the same time, these two industries is one of the biggest industry of China service trade deficit in recent years. However, travel service was a trade surplus industry before 2008, and transport service trade deficit was not so serious before 2009. Another noteworthy industry is consultion, which is developing very well. So we can find that China service industry which has the competitive advantage is still the labor-intensive and resource-intensive industry.
4) The regional structure of China trade in services: From the view of figure 6 to figure 14, we can reach the conclusion that the regional concentration of China trade in services is higher, and the change in the regional concentration is small.

\section{B. Suggestions to Further Improve International Competitiveness of China Trade in Services}

1) Speeding up the transformation of economic development pattern and promoting the transformation and upgrading of the industrial structure: In order to promote the development of service trade, the government should make the clear objectives and well arrangeddevelopment strategies of service industry. China's service trade structure should be transformed gradually and speed up development of knowledge and technology intensive industry, and the high-tech service industry, such as financial services, insurance services, consulting services and ect. should be encouraged to dvelop the independent innovation.

2) Striving to cultivating and introducing the talent who can adapt the international competition enviornment: Owing a group of talents who have the ability to adapt to the international market competition and devote themselves to develop innovation in the service sector is the key of optimizing the structure of service industry.

\section{ACKNOWLEDGMENT}

R.B.G. thanks: This paper is a phased objectives of "Low carbon constraints countermeasures to optimize foreign trade structure of shandong province"(project number:2012EI069), which is a research project of Shandong Economics and Information Technology Committee.

\section{REFERENCES}

[1] Article in a journal: "Balassa B, Export and Economic Growth: Further Evidence”, Journal of Development Economics,1978(5), pp. 181-189.

[2] Article in a journal: He Yongda, "On Theoretical Study of the Transforming Foreign Trade Growth Pattern”. Journal of Lishui University, 2008(12), pp. 41-45.

[3] Falvey, R.\&Gemmell, N.A Formalization and Test of the Factor Productivity Explanation of International Differences in Services Prices[J]. International Economic Review, 1996, 37(1):232- 245.

[4] Franeois,J.Explainingthe Pattern ofTrade in Producer Services [J]. International Economic Journal, 1993(7):135- 163.

[5] Hoekman, B.\&Karsenty, G.Economic Development and International Transaction in Services [J].Development Policy Review, 1992(10):35- 67. 